\title{
ANALISIS KARAKTERISTIK DEMOGRAFI PEKERJA WANITA SEKTOR INFORMAL PADA ERA MASYARAKAT EKONOMI ASEAN DI KOTA PALEMBANG
}

\author{
Armansyah dan Kiki Aryaningrum \\ Program Studi Pendidikan Geografi, Universitas PGRI Palembang \\ Korespondensi: Armansyah (e-mail: armagedone77@yahoo.com)
}

\begin{abstract}
Abstrak
Sektor informal merupakan kegiatan ekonomi alternatif bagi pekerja wanita di Kota Palembang. Selama ini potret sektor informal identik dengan rendahnya upah, pendidikan,kualitas, produktivitas, dan daya saing serta tidak ada keterampilan. Tulisan ini bertujuan untuk membahas karakteristik demografi pekerja wanita sektor informal di Kota Palembang pada era Masyarakat Ekonomi ASEAN (MEA). Metode yang digunakan adalah pendekatan kualitatif, dengan pengumpulan data melalui wawancara, observasi, dokumentasi dan indepth interview. Data yang telah terkumpul dianalisis dengan tahapan reduction, display dan conclution. Keabsahan data diuji dengan derajat credibility yang meliputi; perpanjangan pengamatan, peningkatan ketekunan, dan triangulasi. Hasil penelitian menunjukkan pekerja wanita sektor informal berada pada kelompok usia produktif dan pendidikan setaran SMA ke bawah. Mayoritas mereka memiliki keterampilan tetapi tidak digunakan sebagai modal usaha karena keterbatasan dana, kebanyakan dari mereka juga tidak pernah mengikuti pelatihan, bekerja sebagai pedagang dan tidak memiliki pengetahuan tentang MEA.
\end{abstract}

Kata kunci: karakteristik demografi, pekerja wanita, sektor informal

\section{ANALYSIS OF CHARACTERISTICS DEMOGRAPHY WOMEN WORKER INFORMAL SECTOR IN ERA OF ASEAN ECONOMIC COMMUNITY IN PALEMBANG CITY}

\begin{abstract}
The informal sector is an alternative economic activity for female workers in Palembang City. So far, the portrait of the informal sector is synonymous with low wages, education, quality, productivity, and competitiveness and no skills. This paper aims to discuss the demographic characteristics of informal women workers in the city of Palembang in the era of the ASEAN Economic Community (MEA). The method used is qualitative approach, with data collection through interview, observation, documentation and indepth interview. The collected data is analyzed by the reduction, display and conclution stage. The validity of the data is tested with the degree of credibility that includes; extension of observation, increased perseverance, and triangulation. The results showed that informal sector
\end{abstract}


workers were in the productive age group and lower school education. The vast majority of them have skills but are not used as venture capital because of limited funds, most of them also have never attended training, worked as traders and have no knowledge of MEA.

Keywords:demographic characteristics, women workers, informal sector

\section{Pendahuluan}

Pemberlakuan MEA (Masyarakat Ekonomi ASEAN) sejak Desember 2015 membawa banyak perubahan dalam dinamika pasar Indonesia. Arus mobilisasi pasar bukan hanya pada jenis barang dan investasi tetapi juga tenaga kerja terampil. MEA adalah pasar tunggal bagi negara ASEAN yang berarti persaingan barang, jasa, investasi, dan tenaga kerja bukan lagi pada skala lokal tetapi telah mencapai taraf internasional. Berikut tambahan penjelasan Abdurofiq (2015:254),

"Dalam beberapa kondisi, perekonomian Indonesia mengalami tantangan dalam menghadapi MEA 2015. Pemberlakuan MEA pada 2015 menjadi sebuah realita yang harus dihadapi oleh berbagai sektor industri, ditengah perbandingan kebutuhan pasar dengan tenaga kerja industri yang terjadi saat ini. Ekonomi nasional saat ini banyak didorong oleh kontribusi industri kreatif dengan melibatkan banyak generasi muda yang memiliki kreatifitas dan inovasi yang berorientasi pada Usaha Kecil dan Menengah (UKM)".

Untuk menghadapi kondisi ini, tenaga kerja yang berkualitas dan terampil jelas sangat diperlukan supaya dapat bersaing dengan tenaga kerja dari luar. Di Indonesia penyerapan tenaga kerja selain pada sektor formal juga terjadi pada sektor informal. Sektor informal bahkan merupakan sektor yang menyerap tenaga kerja dalam jumlah yang lebih besar. Keterbatasan kesempatan kerja pada sektor formal membuat sektor informal menjadi alternatif pilihan bagi para tenaga kerja yang gagal memasuki sektor pekerjaan formal.

Sektor informal sarat dengan permasalahan terutama terkait dengan para pekerjanya. Menurut Pitoyo (2007:129) "gambaran umum sektor informal masih identik dengan aktivitas ekonomi skala kecil, kurang produktif, dan tidak mempunyai prospek yang menjanjikan". Selama ini sektor informal digambarkan sebagai wadah bagi para pekerja yang memiliki kualitas rendah yang hanya memanfaatkan sektor ini untuk bertahan hidup atau memenuhi kebutuhan sehari-hari. Padahal menurut Rolis (2013:93) "sektor informal, dengan segala keterbatasannya menyimpan kekuatan luar biasa sebagai penyangga ribuan, bahkan jutaan kelangsungan hidup warga. Dalam banyak penelitian, sektor ini mampu menjadi tempat berlindung hingga 70 persen tenaga kerja di negara sedang berkembang". Sektor informal menjadi lahan yang baik bagi para pekerja wanita. Penyebabnya adalah sektor informal memiliki waktu yang fleksibel sehingga memudahkan para pekerja wanita mengatur waktu antara bekerja dan mengurus rumah tangga. Berikut ini adalah pernyataan Lamba (2011:156) terkait hal tersebut.

"Kehadiran sektor informal perkotaan dianggap sebagai salah satu sektor ekonomi yang muncul sebagai akibat dari situasi pertumbuhan tenaga kerja yang tinggi di kota. Mereka yang memasuki usaha 
berskala kecil ini, pada mulanya bertujuan untuk mencari kesempatan kerja dan menciptakan pendapatan. Kebanyakan dari mereka yang terlibat adalah orang-orang migran darigolongan miskin,berpendidikan rendah dan kurang terampil. Latar belakang mereka bukanlah pengusaha dan juga bukan kapitalis yang mengadakan investasi dengan modal yang besar. Namun harus diakui bahwa banyak di antara mereka telah berhasil mengembangkan usahanya dan secara perlahan-lahan memasuki dunia usaha berskala menengah bahkan berskala besar".

Keterbatasan ekonomi, suami yang tidak/ belum bekerja dan mengisi waktu luang adalah bagian dari alasan para pekerja wanita memilih sektor informal. Dengan demikian peran wanita saat ini bukan hanya sebagai ibu rumah tangga yang ikut membantu perekonomian keluarga. Oleh karena itu kepedulian terhadap pekerja wanita harus lebih ditingkatkan. Ahdiah (2013:1090), menyatakan sebagai berikut.

"Di Indonesia, kepedulian terhadap eksistensi perempuan adalah dengan adanya instruksi Presiden RI No.9 tahun 2000 tentang "Pengarusutamaan Gender dalam Pembangunan Nasional". Sasaran strategi pengarusutamaan gender (PUG) adalah upaya untuk mencapai kesetaraan dan keadilan gender, melalui kebijakan dan program yang memperhatikan pengalaman, aspirasi, kebutuhan, dan permasalahan perempuan dan laki-laki ke dalam seluruh kebijakan di berbagai bidang kehidupan dan pembangunan".

Bentuk kepedulian ini harus semakin ditingkatkan terutama terkait permasalahan saat ini, yaitu kondisi pasar ketenagakerjaan yang telah berubah. Keadaan pasar ekonomi bukan hanya milik penduduk lokal melainkan telah menjadi miliki kawasan negara ASEAN. Informasi ini penting untuk diketahui oleh pekerja wanita sektor informal supaya mulai dari sekarang, mereka dapat meninggalkan kebiasaan dan budaya lama yang menganggap sektor informal hanya sebagai pelarian. Pekerja wanita sektor informal harus mempersiapkan segala hal, baik yang berhubungan dengan pendidikan, keterampilan, kualitas barang, dan lain sebagainya. Hal ini diperlukan untuk meningkatkan daya saing dan produktivitas mereka di ranah ekonomi ASEAN. Berdasarkan data BPS Kota Palembang 2016 jumlah tenaga kerja sektor informal lebih tinggi dibandingkan dengan sektor formal.

Tabel 1 menunjukkan jumlah pekerja sektor informal lebih tinggi dibandingkan dengan yang formal. Hal ini berarti peranannya dalam mengatasi pengangguran di Kota Palembang cukup besar. Sektor informal yang biasanya ditekuni oleh pekerja wanita,misalnya adalah pedagang, jasa, perhotelan, industri, dan pertanian. Berdasarkan data BPS Kota Palembang bidang perdagangan merupakan jenis pekerjaan yang paling banyak dimasuki oleh pekerja wanita.

Tabel 1 Jumlah Pekerja Berdasarkan Jenis Pekerjaan

\begin{tabular}{lcc}
\hline No & Jenis Pekerjaan & Jumlah Pekerja \\
\hline 1 & Formal & 103.939 \\
2 & Informal & 222.345 \\
\hline
\end{tabular}

Sumber: Palembang dalam Angka 2016 
Besarnya jumlah pekerja wanita sektor informal seharusnya menjadi modal bagi pembangunan ekonomi kreatif masyarakat yang dapat mendukung peningkatan ekonomi bangsa. Untuk menjadi sektor yang diandalkan, pekerjanya juga harus memiliki karakterisitik yang baik, seperti; pendidikan tinggi, dan berketerampilan sehingga harapan untuk perbaikan pada sektor informal akan menjadi kenyataan.

Berdasarkan uraian di atas peneliti akan meneliti karakteristik demografi pekerja wanita sektor informal pada era MEA di Kota Palembang. Tujuannya adalah melihat kondisi di lapangan tentang karakteristik pekerja wanita sektor informal. Penelitian ini diharapkan dapat dijadikan bahan evaluasi mengenai hal-hal yang harus diperbaiki dan ditingkatkan yang berhubungan dengan pekerja wanita sektor informal di Kota Palembang.

\section{Metodologi Penelitian}

Penelitian ini menggunakan metode pendekatan kualitatif. Pendekatan inibertujuan untuk mengali karakteristik demografi pekerja wanita sektor infomal di pada era MEA di Kota Palembang secara mendalam. Penelitian ini melakukan kajian pada situasi sosial yang meliputi karakteristik demografi, pekerja wanita, sektor informal dan MEA. Permasalahan penelitian difokuskan pada karakteristik demografi para pekerja wanita sektor informal era MEA di Kota Palembang. Kajian ini bertujuan mendeskripsikan dan menjelaskan kondisi kerakteristik demografi pekerja wanita sektor informal di Kota Palembang pada era MEA.

Pengumpulan data dalam penelitian ini menggunakan teknik wawancara, observasi, dan dokumentasi. Sumber datanya adalah data primer yang diperoleh dari informan yang adalah para pekerja wanita sektor informal yang ada di Kota Palembang. Selain itu, peneliti menggunakan data sekunder seperti: data BPS, jurnal, dan buku. Data yang telah terkumpul dianalisis menggunakan teknik reduction, display, dan conclustion. Sementara itu, teknik keabsahan data menggunakan derajat credibility dengan tahapan perpanjangan pengamatan, peningkatan ketekunan, triangulasi dan pengecekkan data dari anggota peneliti.

\section{Pembahasan}

\section{KarakteristikDemografi Pekerja Wanita Sektor} Informal pada Era MEA di Kota Palembang

Karakteristik demografi adalah ciri-ciri yang melekat pada seorang individu, seperti usia, jenis kelamin, pendidikan, dan pekerjaan. Menurut Kotler dan Armstrong (2001:101) dalam Yoga (2013:1109), demogafi adalah ilmu tentang populasi manusia dalam hal ukuran, kepadatan, lokasi, umur, jenis kelamin, ras, mata pencaharian, dan statistik lainnya. Sementara itu, penelitian Handoyono (2015:3323) mengarahkan penelitiannya pada karakteristik demografi, seperti usia, jenis kelamin, pendidikan dan pendapatan yang mempengaruhi perilaku konsumen. Selanjutnya Riwantoko (2013:81) dalam penelitiannya menyatakan bahwa karakteristik demografi penduduk, seperti usia, jenis kelamin dan pekerjaan berpengaruh pada pola pendapatan ketika menjalankan usaha perdagangan. Penelitian tentang karakteristik demografi juga dilakukan oleh Alfredi (2013:11) seperti berikut ini.

"umur, jumlah keluarga yang terlibat, pendidikan dan jam kerja efektif pendapatan petani penyadap dapat dilakukan dengan meningkatkan tarif getah per kg nya yang berlaku sehingga dapat 
memberikan rangsangan lebih kepada petani penyadap untuk lebih giat lagi menyadap dan menjadikan penyadapan sebagai pekerjaan utama sehingga mampu meningkatkan pendapatan mereka".

Kemampuan dan kualitas tenaga kerja dapat diidentifikasi dari karakteristik demografi yang melekat pada dirinya. Pada era MEA salah satu standar yang digunakan untuk tenaga kerja adalah terampil. Yang dimaksud dengan terampil disini adalah tenaga kerja pada era MEA harus memiliki pendidikan, keterampilan, dan pengetahuan yang baik sehingga nantinya dapat ikut berpartisipasi dalam era MEA. Penelitian ini telah mengkaji karakteristik demografi yang ada pada pekerja wanita sektor informal. Tujuannya adalah untuk menjelaskan kondisi pekerja wanita sektor informal di Kota Palembang saat ini khususnya pada era MEA. Masyarakat Ekonomi Asean (MEA) merupakan tonggak bagi penerapan liberalisasi ASEAN sebagai pasar dan basis produksi tunggal (single market and production base). Penerapannya akan terwujud dalam tiga bentuk, yaitu terjadinya 1) aliran bebas barang/jasa, 2) aliran bebas investasi dan 3) aliran bebas tenaga kerja terampil atau profesional (Usman, 2016:33). MEA adalah tujuan akhir integrasi ekonomi seperti yang dicanangkan dalam ASEAN Vision 2020 berikut."To create a stable, prosperous and highly competitive ASEAN economic goods, services, investment, skill labor economic development and reduced poverty and socio-economic disparities in year 2020." (Abdurofiq, 2015:252). MEA menjadi wadah bagi negara di kawasan Asia Tenggara dalam menjalankan roda perekonomian yang akan meliputi mobilisasi barang, modal/investasi, dan tenaga kerja terampil.
Kajian ini diperlukan karena pekerja wanita merupakan aset bangsa dalam menopang perekonomian, baik skala lokal maupun nasional. Pendapat ini diungkapkan juga oleh Aswiyati (2016:2) yang mengatakan bahwa "wanita Indonesia menjadi tumpuan harapan untuk mendorong laju dan keber-hasilan pembangunan, baik secara luas maupun sempit". Sementara itu, Wauran (2012:1) mengajukan pendapatnya tentang hal itu sebagai berikut.

"Keberadaan dan kelangsungan kegiatan sektor informal dalam sistem ekonomi kotemporer bukanlah gejala negatif, namun lebih sebagai realitas ekonomi kerakyatan yang berperan cukup penting dalam pengembangan masyarakat dan pembangunan nasional. Setidaknya, ketika program pembangunan kurang mampu menyediakan peluang kerja bagi angkatan kerja, sektor informal dengan segala kekurangannya mampu berperan sebagai penampung dan alternatif peluang kerja bagi para pencari kerja".

Ada beberapa faktor yang menyebabkan wanita bekerja.Penelitian Soebyakto dan Armansyah (2016:131) menunjukkan hal berikut ini.

"The dominant factors that cause migrant women working in the informal sector is the desire to help the family income, flexible working time, The desire to help the family income is the biggest cause of migrant women working in the informal sector with the percentage of $100 \%$ of the number of migrant women working in the informal sector said that the reason they work in the informal sector because they want to help the family income". 
Tabel 2 Jumlah Pekerja Wanita Sektor Informal Berdasarkan Kelompok Usia

\begin{tabular}{ccc}
\hline Kelompok Umur & Jumlah & Keterangan \\
\hline $15-19$ & 17 & \\
$20-24$ & 35 & \\
$25-29$ & 6 & \\
$30-34$ & 6 & \\
$35-39$ & 9 & \\
$40-44$ & 15 & \\
$45-49$ & 8 & \\
$50-54$ & 4 & \\
$55-59$ & 6 & \\
$60-64$ & 2 & \\
\hline $65+$ & 0 & \\
\hline Total & 108 & \\
\hline
\end{tabular}

Sumber: Pengolahan Data Lapangan, 2017

Berdasarkan temuan di atas dapat dikatakan bahwa penyebab dominan wanita bekerja di sektor informal disebabkan keinginan untuk membantu meningkatkan pendapatan keluarga. MenurutRisnawati (2016:117) faktor seperti pendapatan suami yang belum mampu memenuhi kebutuhan keluarga dan banyaknya tanggungan keluarga juga merupakan penyebab wanita memutuskan untuk bekerja pada sektor informal. Sementara itu, karakteristik demografi yang peneliti lihat pada penelitian ini meliputi usia, pendidikan, keterampilan, pelatihan, pekerjaan, dan pengetahuan tentang MEA. Uraiannya dapat dilihat pada bagian di bawah ini.

\section{(1) Usia}

Usia sangat menentukan tingkat produktivitas seorang pekerja. Jika usia pekerja terlalu muda perkembangannya dalam meningkatkan kualitas diri seperti meningkatkan pendidikan dan keterampilan akan terganggu. Namun, jika terlalu tua, maka tingkat produktivitas juga akan menurun sehingga kesulitan mengikuti persaingan global. Penelitian ini menemukan bahwa mayoritas pekerja wanita sektor informal merupakan kelompok usia produktif, yaitu antara 20-24 tahun, yang dapat dilihat pada tabel di berikut ini.

Berdasarkan Tabel 2 dapat dijelaskan bahwa kelompok usia 20-24 mendominasi pekerja wanita sektor informal dan jika dikelompokkan berdasarkan usia maka semua pekerja wanita di atas merupakan kelompok usia produktif. Berdasarkan hasil penelitian Dwipawati (2013:5) puncakumur pekerja wanita adalah antara 21-25 tahun dan tingkat pendidikan yang mendominasi adalah SMASMK. Hal ini karena keterbatasan biaya untuk melanjutkan pendidikan ke jenjang yang lebih tinggi. Selanjutnya jika dilihat dari kelompok usia, maka pekerja wanita sektor informal di Kota Palembang masih tergolong produktif dan mampu bersaing. Yang perlu dilakukan kemudian adalah manajemen untuk meningkatkan kualitas dan produktivitas para pekerja wanita sektor informal. Dengan demikianpada era MEA, mereka mampu bersaing dan ikut berpartisipasi dalam wadah pasar ASEAN. 


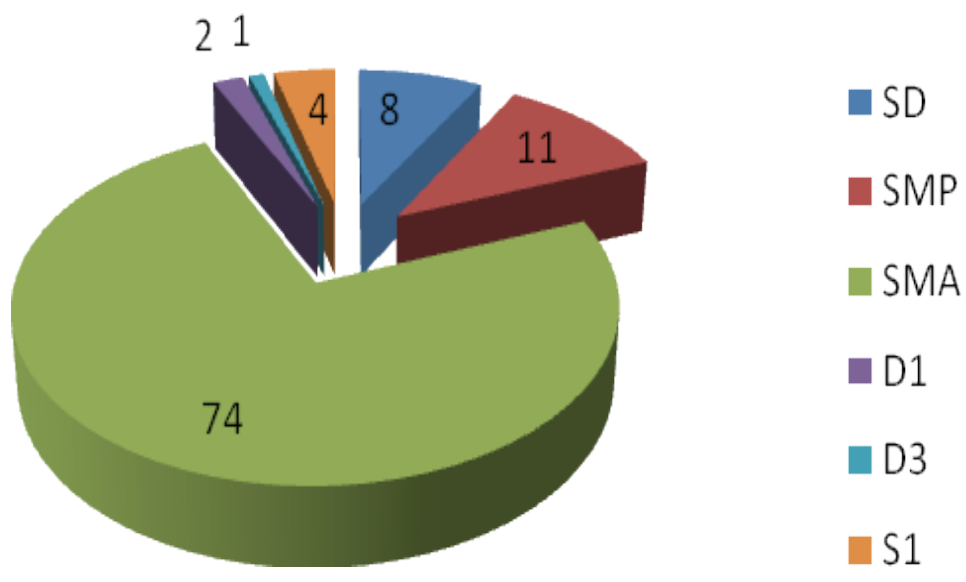

Sumber: Pengolahan Data Lapangan Tahun 2017

Gambar 1 Persentase Pekerja Wanita Berdasarkan Tingkat Pendidikan

(2) Pendidikan

Pendidikan juga menjadi tolak ukur keberhasilan seorang pekerja. Semakin baik pendidikan seseorang akan semakin baik pula tingkat kesejahteraan individu tersebut. Dalam era MEA, pendidikan minimal SMA/ SMK sangat diperlukan sehingga mampu bersaing dalam dunia kerja ASEAN. Peneliti menemukan bahwa tingkat pendidikan pekerja wanita di Kota Palembang mayoritas adalah setara SMA ke bawah. Datanya dapat dilihat pada gambar di bawah ini.

Gambar tersebut menunjukkan bahwa tingkat pendidikan pekerja wanita sektor informal dominan pada level SMA disusul oleh SMP dan SD. Hal ini berarti, jika dilihat dari karakteristik pendidikan pekerja wanita sektor informal yang ada di Kota Palembang masih tergolong rendah. Alasannya adalah karena tingkat pendidikan pekerja wanita masih banyak dari level SMA ke bawah. Padahal pada era MEA tingkat pendidikan yang diharuskan adalah SMA/SMK ke atas.

Kondisi ini menjelaskan bahwa walaupun usia pekerja wanita sektor informal di Kota Palembang tergolong produktif, tingkat pendidikan mereka masih rendah. Hal itu disebabkan oleh latar belakang keluarga mereka yang kurang mampu sehingga terkendala biaya untuk melanjutkan pendidikan. Oleh sebab itu, perlu

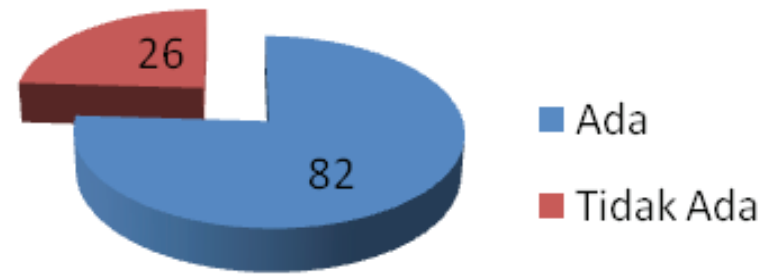

Sumber: Pengolahan Data Lapangan 2017

Gambar 2 Jumlah Pekerja Wanita Berdasarkan Keterampilan 
perhatian khusus dari pemerintah untuk mengupayakanagar para pekerja wanita sektor informal, terutama yang masih berusia 15-24 tahun, dapat ditingkatkan pendidikan dan keterampilannya.Dengan demikian, nantinya mereka dapat memiliki pendidikan yang memadai.

\section{(3) Keterampilan}

Pada hakikatnya pendidikan berdampak pada keterampilan, sehingga jika mereka berpendidikan tinggi, keterampilan yang dimiliki juga baik. Namun, hal ini berbeda pada kondisi pekerja wanita sektor informal di Kota Palembang. Mayoritas mereka tidak memiliki keterampilan untuk digunakan dalam memperoleh pendapatan.

Gambar tersebut menunjukkan bahwa kebanyakan pekerja wanita sektor informal di Kota Palembang mengaku memiliki keterampilan yang cukup memadai untuk dapat digunakan sebagai alat bekerja memperoleh pendapatan.Beberapa diantara mereka memperoleh keterampilan dengan cara belajar dari keluarga, seperti orang tua, paman, bibi, teman dan lain-lain. Ada juga yang mengikuti pelatihan yang diselengarakan oleh pemerintah atau swasta, bahkan ada juga yang membayar sendiri untuk mengikuti kursus pelatihan namun jumlah mereka relatif kecil. Jenis keterampilan yang dimiliki oleh pekerja wanita sektor informal adalah, seperti menjahit, memasak, menari, salon, dan menyablon. Meskipun mayoritas pekerja wanita memiliki keterampilan, tetapi tidak serta merta keterampilan tersebut dapat mereka gunakan sebagai modal bekerja. Banyak pekerja wanita sektor informal yang tidak menggunakan keterampilan yang mereka miliki dikarenakan keterbatasan modal untuk mengembangkan keterampilan yang mereka miliki sehingga akhirnya mereka memilih pekerjaan yang mudah dijalankan seperti; berdagang, dan menjadi pelayan toko atau karyawan.

\section{(4) Pelatihan}

Pelatihan merupakan hal yang penting bagi para pekerja wanita sektor informal. Melalui pelatihan mereka dapat meningkatkan keterampilan dan memiliki pemikiran dapat mengembangkan usaha ke arah yang lebih baik. Selain itu, adanya pelatihan akan meningkatkan keterampilan pekerja wanita sektor informal dalam mengolah dan meningkatkan produk yang mereka hasilkan. Tentunya pelatihan tersebut harus relevan dengan pekerjaan yang kebanyakan dilakukan oleh para pekerja wanita sektor informal di Kota Palembang.

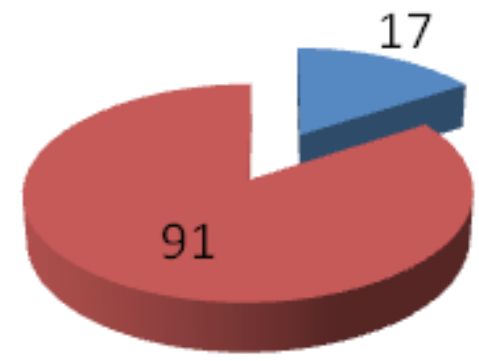

\section{Pernah}

Tidak Pernah

Sumber: Pengolahan Data Lapangan 2017

Gambar 3 Jumlah Pekerja Wanita Sektor Informal Berdasarkan Kegiatan Pelatihan 
Berdasarkan gambar di atas dapat dijelaskan bahwa mayoritas pekerja wanita sektor informal menyatakan mereka tidak pernah mengikuti pelatihan. Faktanya menunjukkan bahwa dari 108 pekerja wanita sektor informal hanya 17 orang yang pernah mengikuti pelatihan, sedangkan 91 lainnya tidak pernah mengikuti pelatihan. Kondisi ini menjelaskan bahwa rendahnya keterampilan, produktivitas, dan kualitas pekerja wanita sektor informal merupakanhal yang wajar karena mereka kebanyakan tidak atau belum pernah mengikuti pelatihan, baik yang diadakan oleh pemerintah ataupun pihak swasta. Yang menjadi pertanyaan kemudian adalah apakah hal itu disebabkan oleh kurang sosialisasi dari pemerintah atau pihak swasta ketika mengadakan pelatihan atau karena pekerja wanita sektor informal kurang peduli untuk mengikuti pelatihan? Namun, yang paling penting adalah adanya kerja sama antara pemerintah/swasta dan masyarakat, terutama pekerja wanita, sehingga dapat mewujudkan tenaga kerja terampil era MEA.

(5) Pekerjaan

Jenis pekerjaan yang dilakukan akan berpengaruh pada pendapatan yang dihasilkan. Pada sektor informal pekerjaan yang paling banyak ditekuni adalah sebagai pedagang.
Hal yang sama juga terjadi dengan pekerja wanita sektor informal di Kota Palembang yang mayoritas bekerja sebagai pedagang.

Gambar 4 menunjukkan bahwa dari 108 pekerja wanita sektor informal di Kota Palembang terdapat 85 orang yang bekerja sebagai pedagang, 10 orang sebagai karyawan, 3 orang pada bidang jasa, dan 2 orang bekerja sebagai pengajar privat. Kondisi ini juga sama seperti kebanyakan kajian tentang sektor informal lainnya yang menunjukkan bahwa kebanyakan sektor informal yang ditekuni oleh para pekerjanya adalah berdagang.

Alasan pekerja wanita sektor informal memilih berdagang adalah karena waktu kerja yang lebih fleksibel sehingga memungkinkan mereka untuk menjalankan pekerjaan sebagai pedagang. Sebagai seorang wanita yang memiliki multiperan, maka pekerja wanita harus dapat membagi waktu antara bekerja, mengurus anak, mengurus suami, mengurus rumah, dan lain-lain. Pendapat ini sejalan dengan yang diungkapkan oleh Abdullah (2001) dalam Warsito (2013:149) "dalam keluarga, seorang perempuan memiliki peran sebagai ibu rumah tangga yang bertugas merawat anak dan melayani suami”. Pekerja wanita sektor informal mengungkapkan bahwa berdagang adalah pilihan yang tepat karena mereka dapat bekerja sesuai keinginan mereka tanpa ada aturan atau paksaan dari

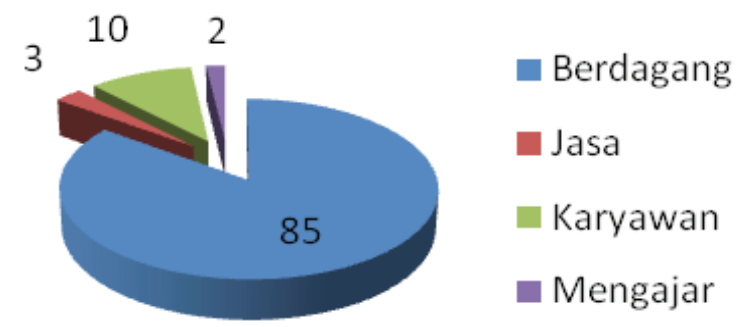

Sumber: Pengolahan Data Lapangan 2017

Gambar 4 Jumlah Pekerja Wanita Berdasarkan Jenis Pekerjaan 


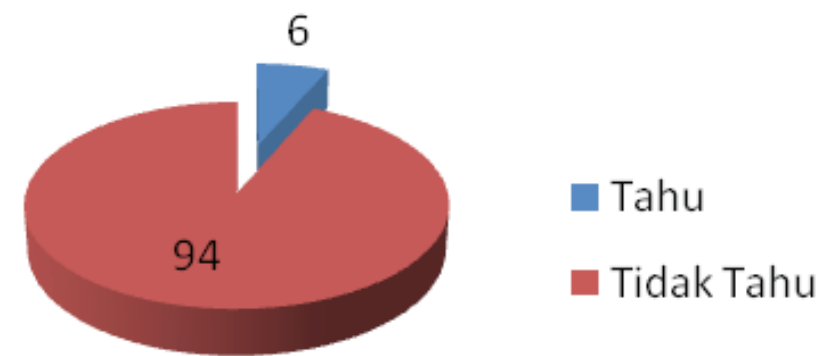

Sumber: Pengolahan Data Lapangan 2017

\section{Gambar 5 Jumlah Pekerja Wanita Berdasarkan Pengetahuan Tentang MEA}

Melihat kondisi ini seharusnya pemerintah dan pihak yang terkait mampu memberikan dukungan berupa pinjaman modal bagi para pekerja wanita sektor informal sehingga mereka dapat mengembangkan usaha perdagangan yang mereka jalankan. Selama ini pekerja wanita sektor informal yang bekerja sebagai pedagang hanya bekerja seadanya tanpa ada pemikiran untuk meningkatkan atau mengembangkan usahanya. Padahal jika sektor ini mendapat perhatian yang baik maka dapat dipastikan akan bermunculan ekonomi-ekonomi kreatif dari masyarakat sehingga akan menghidupkan ekonomi kerakyatan.

(6) Pengetahuan tentang MEA

Sejak Desember 2015 MEA telah dilaksanakan oleh negara-negara yang ada di kawasan Asia Tenggara. Sebagai masyarakat ASEAN, Indonesia menjadi bagian dari pasar tunggal ASEAN sehingga barang, modal/ investasi, dan tenaga kerja terampil bebas masuk di Indonesia. Bagi kalangan tertentu, seperti insan pendidikan mungkin tidak asing lagi mendengar kata MEA. Namun bagi kalangan masyarakat pada umumnya belum diketahui sejauh mana pemahaman mereka tentang MEA. Peneliti menemukan fakta bahwa mayoritas pekerja wanita sektor informal di Kota Palembang yang dijadikan informan dalam penelitian ini mengatakan tidak mengetahui bahkan ada yang belum pernah mendengar tentang MEA.

Gambar 5 menunjukkan 94 orang dari 108 pekerja wanita sektor informal di Kota Palembang mengatakan bahwa mereka belum mengetahui dan mendengar tentang MEA. Sangat miris karena program yang begitu besar dan meliputi wilayah ASEANbelum pernah didengar oleh masyarakat bawah Kondisi ini menguatkan alasan pekerja wanita sektor informal masih menjalankan usahanya dengan cara dan pola yang sama. Penyebabnya adalah karena mereka tidak mengetahui tentang tantangan yang akan mereka hadapi di depan. Melihat hal ini, sangat perlu dilakukan sosialisasi tentang MEA melalui berbagai media dan partisipan sehingga mata masyarakat Indonesia dan Kota Palembang khususnya akan terbuka tentang tantangan yang akan mereka hadapi. Jika hal itu dilakukan, maka diharapkan kesadaran para pekerja sektor informal di Kota Palembang, khususnya wanita dapat ditingkatkan demi produktivitas dan kualitas diri yang lebih baik serta berhasil usaha yang dijalankan.Dengan demikian, pada saatnya nanti penduduk Indonesia dan Kota Palembang pada khususnya akan menjadi pemain dalam kancah MEA. 


\section{Penutup}

\section{Kesimpulan}

Karakteristik demografi yang melekat pada pekerja akan mempengaruhi kemampuan, kualitas, dan produktivitasnya dalam bekerja. Penelitian ini menemukan bahwa pekerja wanita sektor informal di Kota Palembang memiliki karakteristik demografi, seperti termasuk dalam kelompok usia produktif, yaitu kelompok yang paling dominan ada pada usia 20-24 tahun.

Pendidikan pekerja wanita sektor informal mayoritas setingkat SMA ke bawah. Pekerja wanita sektor informal di Kota Palembang mayoritas memiliki keterampilan, tetapi tidak digunakan sebagai modal untuk menjalankan usaha karena keterbatasan dana. Kemudian mayoritas pekerja wanita sektor informal belum mengikuti pelatihan. Pekerjaan yang banyak dilakukan oleh pekerja wanita sektor informal adalah berdagang. Selanjunya pekerja wanita sektor informal mayoritas tidak memiliki pengetahuan tentang MEA sehingga mereka tidak memiliki kesadaran untuk meningkatkan kualitas dan produktivitas agar dapat bersaing dalam era MEA.

\section{Saran}

Pemerintah ataupun pihak yang terkait harus dapat melakukan strategi dalam meningkatkan kualitas dan produktivitas pekerja wanita sektor informal di Kota Palembang sehingga mampu bersaing dalam era MEA. Bentuk strategi yang dapat dilakukan seperti; melakukan pelatihan, peminjaman modal dan yang terpenting melakukan sosialisasi tentang MEA ke masyarakat secara lebih baik. Pada penelitian selanjutnya disarankan agar dapat dilakukan kajian tentang cara atau model yang dapat diterapkan untuk meningkatkan kualitas dan produktivitas pekerja wanita sektor informal. Selain itu juga perlu dilakukan kajian tentang optimalisasi pedagang sektor informal supaya dapat berkembang dan mampu bersaing dalam era MEA.

\section{Daftar Pustaka}

Abdurofiq, Atep. 2015. "Menakar Pengaruh masyarakat Ekonomi Asean 2015 Terhadap Pembangunan Indonesia". Jurnal Filsafat dan Budaya Hukum. http://journal.uinjkt. ac.id/index.php/salam/article/viewFile/1543/ pdf. Diunduh pada 06 Mei 2017, 13:11 WIB. Ahdiah, Indah. 2013. "Peran-peran Perempuan dalam Masyarakat”. Jurnal Academica Fisip Untad, Vol. 5, No. 2, Oktober.

Alfredi; dkk. 2013. "Pengaruh Karakteristik Demografi, Sosial, dan Ekonomi Terhadap Pendapatan Petani Penyadap Getah Pinus di Kecamatan Sesena Padang Kabupaten Mamasa".http://pasca. unhas.ac.id/jurnal/files/41aa84c963cba5 244fb87db4d09886cb.pdf, Diunduh pada 06 Mei 2017, 10:32 WIB.

Aswiyati, Indah. 2016. "Peran Wanita dalam Menunjang Perekonomian Rumah Tangga Keluarga Petani Tradisional untuk Penanggulangan Kemiskinan di Desa Kuwil Kecamatan Kalawat". Jurnal Holistik, Tahun IX, No. 17 / Januari-Juni..

Dwipawati, Ni Made Gunarsih. 2013. "Keterlibatan Pekerja Wanita pada Industri Kerajinan Seni Ukir dan Lukis di Desa Singakerta, Kecamatan Ubud, Kabupaten Gianyar (Tinjauan Geografi Ekonomi)". ejournal.undiksha.ac.id/index.php/JJPG/ article/download/1223/1087, Diunduh pada 16 April 2017, 21:31 WIB.

Handoyono, I Gede Suryana Ryan; Putu Yudi 
Setiawan. 2015. "Pengaruh Karakteristik Demografi dan Ketidakpuasan Terhadap Perilaku Mengeluh Konsumen pada Bengkel Service Sepeda Motor Yamaha di Ponorogo Denpasar Bali". E-jurnal Manajemen Unud, Vol.4, No. 10, 2015: 3317-2245.

Lamba, Arung. 2011. "Kondisi Sektor Informal Perkotaan dalam Perekonomian JayapuraPapua". Jurnal Ekonomi Bisnis, TH. 16, No. 2, Juli 2011. http://fe.um.ac.id/wp-content/ uploads/2009/10/9-Arung-Lamba.pdf, Diunduh pada 06 Mei 2017, 11:37 WIB.

Pitoyo, Agus Joko. 2007. "Dinamika Sektor Informal di Indoensia Prospek, Perkembangan, dan Kedudukannya dalam Sistem Ekonomi Makro". Jurnal Populasi, 18(2), https://jurnal.ugm.ac.id/populasi/ article/viewFile/12081/8868, Diunduh pada 06 Mei2017, 12:52 WIB.

Risnawati. 2016. "Peran Ganda Istri yang Bekerja dalam Membantu Ekonomi Keluarga Buruh Perkebunan Kelapa Sawit pada PT. Bumi Mas Agro Kecamatan Sandaran Kabupaten Kutai Timur". eJournal Sosiatri-Sosiologi, 2016, 4(3): 113-126.

Riwantoko, Mardheka Ndaru; Abdur Rofi.2013. "Karakteristik Demografi, Sosial, dan Ekonomi serta Pola Pendapatan Usaha Perdagangan di Sepanjang Jalan Jogja-Solo Kabupaten Klaten". http://lib. geo.ugm.ac.id/ojs/index.php/jbi/article/ viewFile/130/127, Diunduh pada 06 Mei 2017, 10:20 WIB.

Rolis, Moh. Ilyas. 2013. "Sektor Informal Perkotaan dan Ikhtiar Pemberdayaanya". Jurnal Sosiologi Islam, Vol. 3, No. 2, Oktober.

Soebyakto, Bambang Bemby; Armansyah. 2016. "Migran Women Working at Informal Sectors: Empirical Study in Kuto Batu Village, Ilir Timur II Palembang City".
International Journal of Humanities and Social Science, Vol. 6, No. 4; April 2016. Usman, Fajar. 2016. "Masyarakat Ekonomi Asean (MEA) dan Daya Saing Investasi Indonesia". Jurnal Lingkar Widyaiswara, Edisi 3, No. 1, Jan-Mar.

Warsito. 2013. "Perempuan dalam Keluarga Menurut Konsep Islam dan Barat". Profetika, Jurnal Studi Islam, Vol. 14, No. 2, Desember 2013: 148-163.

Wauran, Patrick C. 2012. "Strategi Pemberdayaan Sektor Informal Perkotaan di Kota Manado. Jurnal Pembangunan Ekonomi dan Keuangan Daerah (PEKD)", Vol.7, No. 3, Edisi Oktober 2012. http:// download. portalgaruda.org/article. php?article $=107033 \&$ val $=997$, Diunduh pada 06 Mei 2017, 10:54 WIB.

Yoga, I Made Sedana; Gede Ketut Warmika. 2013. "Hubungan Karakteristik Demografi Dengan Perilaku Keluhan Konsumen". http://download. portalgaruda.org/article. php?article $=82483 \&$ val $=989$, Diunduh pada 06 Mei 2017, 09:50 WIB. 